\title{
OPTIMALISASI PERAN SATLINMAS DI KELURAHAN GILINGAN KECAMATAN BANJARSARI KOTA SURAKARTA
}

\author{
${ }^{1}$ Wulan Kinasih, ${ }^{2}$ Joko Pramono \\ Universitas Slamet Riyadi, Surakarta \\ Email: \\ ${ }^{1}$ kinasihkudo@gmail.com
}

\begin{abstract}
Indonesia's defense and security system embraces Sishankamrata system. In the case of realizing this sishankamrata, the formation of hansip or community as a component of society which cooperates with TNI and POLRI in realizing security, public order and protection. This study aims to describe the optimization of Satlinmas in Gilingan, Surakarta. The method used in this research is descriptive qualitative. Research data in the form of events obtained from observations and interviews, and supporting documents. Researchers get data by way of observation, interview and documentation. The data were analyzed using interactive analytical models of Miles, Huberman and Saldana. The results showed that the optimization has been implemented in accordance with the role of Satlinmas as stipulated in Permendagri No.84 of 2014 and Surakarta Mayor Regulation No.58 A in 2012. Satlinmas is active in assisting disaster management, both natural and disaster caused by the outbreak of disease outbreak, conducting routine patrols in every area, especially vulnerable areas, assisting community social activities, assisting in the election and defense of the State.
\end{abstract}

Key words: Optimization; Community Protection; Satlinmas

\section{PENDAHULUAN}

Manusia sebagai makhluk hidup memiliki kebutuhan yang harus dipenuhi. Kebutuhan manusia dalam segi tingkatan kepentingannya dibagi menjadi kebutuhan primer, sekunder dan tersier. Kebutuhan primer adalah kebutuhan dasar yang sangat penting bagi orang yang bersangkutan sehingga kebutuhan ini haruslah dipenuhi terlebih dahulu dan paling utama. Kebutuhan ini merupakan unsur-unsur yang dibutuhkan oleh manusia dalam mempertahankan keseimbangan fisiologis maupuan psikologis, yang tentunya bertujuan untuk mempertahankan kehidupan dan kesehatan. Kebutuhan dasar manusia menurut Abraham Maslow (1994) dalam teori hirarki kebutuhan menyatakan bahwa setiap manusia memiliki lima kebutuhan dasar yaitu kebutuhan fisiologis, keamanan, cinta, harga diri, dan aktualisasi diri. Setelah kebutuhan-kebutuhan fisiologis terpuaskan secukupnya, muncullah apa yang disebut Maslow sebagai kebutuhan akan rasa aman.

Rasa aman merupakan kewajiban yang harus dipenuhi oleh setiap Negara terhadap warga negaranya. Indonesia mengatur tentang keamanan warga negaranya seperti yang termuat dalam UUD 1945. Dalam pasal 30 ayat 1 UUD 1945 "tiap-tiap warga negara berhak dan wajib ikut serta dalam usaha pertahanan dan keamanan negara". Maksud dari pasal 30 ayat 1 UUD 1945 disini menjelaskan bahwa setiap warga negara Indonesia mempunyai hak yang sama yaitu hak untuk ikut serta dalam menjaga pertahanan dan keamanan negara. Yang Berarti warga negara diharuskan supaya bisa turut serta dalam usaha mempertahanan Negara dan menciptakan keamanan dari gangguan, ancaman baik itu dari luar maupun dari dalam negeri. Pasal 30 ayat 2 UUD 1945 "usaha pertahanan dan keamanan negara dilaksanakan melalui sistem pertahanan dan 
keamanan rakyat semesta oleh Tentara Nasional Indonesia dan Kepolisisan Negara Republik Indonesia, sebagai kekuatan utama, dan rakyat sebagai kekuatan pendukung." Berdasarkan uraian tersebut, pertahanan dan keamanan bukan hanya menjadi tanggung jawab TNI dan POLRI tetapi juga menjadi tanggung jawab warga Negara atau yang disebut dengan Sishankamrata.

Sishankamrata merupakan sistem keamanan dan pertahanan yang melibatkan seluruh elemen warga Negara. Komponen sishankamrata adalah pertanahan militer yang meliputi TNI dan POLRI dan non militer yaitu rakyat Indonesia. TNI berfungsi sebagai alat pertahanan NKRI sedangkan POLRI berfungsi mengatur keamanan dan ketertiban masyaakat. TNI dan POLRI adalah komponen utama dalam sishankamrata sedangkan rakyat Indonesia adalah komponen pendukung. Dalam hal mewujudkan sishankamrata ini,dibentuklah hansip atau linmas sebagai komponen masyarakat yang bekerjasama dengan TNI dan POLRI dalam mewujudkan keamanan, ketertiban dan perlindungan masyarakat.

Linmas memiliki peran yang sangat penting dalam mendukung keamanan, ketertiban dan perlindungan masyarakat. Berdasarkan permendagri No.84 tahun 2014 pasal 1 ayat 1 Penyelenggaraan perlindungan masyarakat adalah pengorganisasian dan pemberdayaan perlindungan masyarakat. Dalam ayat 3 kemudian disebutkan bahwa Satuan Perlindungan Masyarakat yang selanjutnya disebut Satlinmas adalah Organisasi yang dibentuk oleh pemerintah Desa/Kelurahan dan beranggotakan warga masyarakat yang disiapkan dan dibekali pengetahuan serta keterampilan untuk melaksanakan kegiatan penanganan bencana guna mengurangi dan memperkecil akibat bencana, serta ikut memelihara keamanan, ketenteraman dan ketertiban masyarakat, kegiatan sosial kemasyarakatan. Berdasarkan amanat tersebut, linmas merupakan organisasi kemasyarakatan yang pentting dalam membantu menciptakan keamanan, dan ketertiban di daerah. Salah satu daerah yang memberdayakan masyarakat dalam satlinmas adalah adalah kota Surakarta.

Peran linmas, diharapkan dapat membantu TNI dan POLRI dalam mewujudkan keamanan dan ketertiban serta penanggulangan bencana alam dan sosial. Namun berdasarkan hasil monitoring evaluasi dan pelaporan satuan perlindungan masyarakat kota Surakarta tahun 2012 dari Bappeda kota Surakarta menyatakan bahwa kondisi Linmas di Kota Surakarta masih terkesan ala kadarnya. Tidak ada keunggulan yang khusus. Linmas hanya dikenal sebagai penjaga keamanan kantor kelurahan/kecamatan. Fungsi perlindungan keamanan dan kenyamanan juga tidak mempunyai greget di mata masyarakat. hal serupa juga disampaikan oleh anggota Komisi I DPRD kota Surakarta Budi Prasetyo menyatakan bahwa kinerja linmas tak maksimal, seharusnya Linmas kota dapat berperan lebih, salah satunya dalam upaya penegakan Perda (Putradi Pamungkas. Joglo Semar, Jumat, 29/01/2016). Kurang optimalnya peran linmas ini akan berdampak pada kondisi keamanan dan ketentraman masyarakat. berdasarkan kajian deteksi dini kerawanan sosial dan kriminalitas Kota Surakarta yang dilakukan oleh Bappeda pada tahun 2016, terjadi peningkatan angka kerawanan sosial dan kriminalitas. Pada tahun 2014 jumlah tindak kriminalitas yang tercatat adalah 280 kasus dan mengalami peningkatan pada tahun 2015 menjadi 302 kasus. Pada tahun 2016 tindak kriminalitas meningkat tajam, berdasarkan data dari Polresta Surakarta, selama 2016 telah mengungkap 1.182 kasus kriminalitas. Selain dari sisi kriminalitas, kota Surakarta juga termasuk kategori rawan bencana terutama bencana banjir, kekeringan, dan gempa bumi. 
Berdasarkan permasalahan tersebut maka perlu optimalisasi peran linmas untuk menciptakan kondisi masyarakat yang aman dan tenteram. Penelitian ini, mendeskripsikan optimalisasi peran linmas di kelurahan Gilingan kecamatan Banjarsari. Lokasi ini diambil karena kecamatan tersebut memiliki personil linmas yang lebih banyak disbanding dengan kecamatan lain. selain itu, kecamatan Banjarsari merupakan jalan masuk menuju Kota Surakarta. Banyaknya pendatang baru menjadi faktor pemicu terjadinya kerawanan sosial dan kriminalitas.

\section{METODE PENELITIAN}

Jenis penelitian dalam penelitian ini adalah penelitian kualitatif deskriptif. Data diperoleh dengan cara observasi, wawancara dan dokumentasi. Analisis data pada penelitian ini menggunakan analisis data model analisis interaktif Miles \& Huberman. Langkah-langkah analisis data model interaktif Miles dan Huberman di gambarkan sebagai berikut:

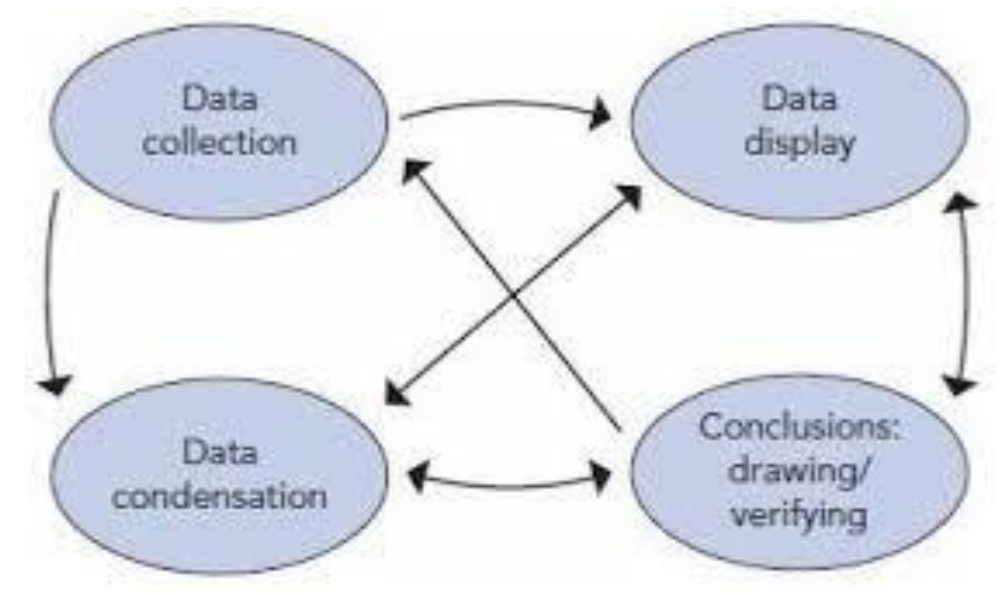

\section{Gambar 1.Komponen-Komponen Analisis Data Model Interaktif}

Sumber: Miles, Huberman dan Saldana (2014)

\section{PEMBAHASAN}

Satinmas merupakan satuan di bawah Satpol PP yang berperan dalam membantu terciptanya ketertiban dan keamanan di lingkungan masing-masing. Satlinmas berada di setiap kelurahan. Keberadaannya yang dekat dengan masyarakat diharapkan mampu membantu pemerintah daerah, Polisi dan TNI. Optimalisasi peran Satlinmas di perlukan sebagai upaya dalam memperkuat peran serta masyarakat dalam menjaga lingkungan sendiri. Optimalisasi dilakukan sesuai dengan peran Satlinmas yang tertuang dalam Permendagri No.84 tahun 2014 dan Peraturan Wali Kota Surakarta No.58 A tahun 2012.

Peran pertama Satlinmas adalah membantu upaya penanggulangan bencana.
Satlinmas kelurahan Gilingan berperan aktif dalam upaya penangguangan bencana, baik yang diakibatkan oleh bencana alam maupun akibat adanya ledakan penyakit. Bencana alam yang sering terjadi di kelurahan Gilingan adalah bencana banjir. Bencana banjir ini diakibatkan oleh meluapnya sungai anak bengawan solo yang melintasi kelurahan tersebut. Dalam mengendalikan dan mengurangi dampak banjir, satlinmas aktif dalam berbagai kegiatan seperti normalisasi sungai, menjaga kebersihan sungai, pelatihan tanggap bencana, dan pengawasan debit air. Satlinmas siap siaga ketika kondisi air sungai mulai naik. Kesiapsiagaan merupakan serangkaian kegiatan yang dilakukan untuk mengantisipasi bencana melalui 
pengorganisasian serta melalui langkah yang tepat guna dan berdaya guna. (UU No 24 Tahun 2007 Tentang Penanggulangan Bencana). Penanganan bahaya banjir dapat dilakukan dengan cara struktural dan non struktural. Penanganan yang bersifat non struktural adalah suatu kegiatan penyesuaian sedemikian rupa sehingga jika terjadi bencana banjir, maka kerugian bencana yang ditimbulkannya dapat ditekan sekecil mungkin dan untuk meningkatkan kewaspadaan masyarakat dalam menghadapi bencana banjir. Dalam melaksanakan kegiatan ini Satlinmas bekerjasama dengan masyarakat setempat.

Selain bencana alam karena banjir, kelurahan Gilingan juga waspada terhadap bencana akibat wabah penyakit. Bencana yang diakibatkan oleh wabah penyakit yang rawan terjadi di kelurahan Gilingan adalah demam berdarah dan infeksi HIV/AIDS. Satlinmas membantu terselenggaranya terselenggaranya kegiatan HCT dan sosialisasi tentang infeksi HIV/AIDS. Dalam mengatasi penyebaran wabah demam berdarah, penanggulangan ledakan penyakit juga dilakukan dengan aktif membantu kegiatan sosialisasi 3M. Gerakan ini dilakukan secara bersama sama antar dinas kesehatan, kelurahan dan dibantu Satlinmas.

Peran Satlinmas yang kedua adalah membantu terciptanya keamanan dan ketertiban dalam masyarakat. Pasal 1 Undang-undang Kepolisian Negara Republik Indonesia Nomor 2 Tahun 2002 disebutkan bahwa pengertian Kamtibmas adalah suatu kondisi dinamis masyarakat sebagai salah satu prasyarat terselenggaranya proses pembangunan nasional dalam rangka tercapainnya tujuan nasional yang ditandai oleh terjaminnya keamanan, ketertiban, dan tegaknya hukum, serta terbinanya ketentraman yang mengandung kemampuan membina serta mengembangkan potensi dan kekuatan masyarakat dalam menangkal, mencegah, dan menanggulangi segala bentuk pelanggaran hukum dan bentuk-bentuk gangguan lainnya yang dapat meresahkan masyarakat. Satlinmas Kelurahan Gilingan melakukan tugasnya secara optimal dalam terciptanya keamanan, kenyamanan dan ketertiban. Satlinmas Gilingan secara rutin melakukan patroli keliling terutama di tempat-tempat yang ramai masyarakat seperti tempat wisata. Satlinmas juga membantu satpol PP dalam melakukan operasi pekat karena banyaknya PSK di wilayah sekitar terminal. Untuk mengantisipasi peredaran gelap narkoba, Satlinmas Gilingan juga menjadi mitra kepolisian dalam mengawasi adanya indikasi peredaan narkoba. Selain itu, satlimas juga selalu membantu terselenggaranya acara kebudayaan di kelurahan Gilingan.

Peran Satlinmas yang ketiga adalah membantu dalam kegiatan sosial kemasyarakatan. Salah satu peran satlinmas yang paling dekat dengan masyarakat adalah membantu dalam kegiatan sosial kemasyarakatan Menurut Mac Iver dan Page dalam Soekanto masyarakat ialah suatu sistem dari kebiasaan dan tata cara, dari wewenang dan kerja sama antara berbagai kelompok dan penggolongan dan pengawasan tingkah laku serta kebebasankebebasan manusia. Masyarakat merupakan jalinan hubungan sosial, dan masyarakat selalu berubah (Soekanto, 2007: 22). Suatu masyarakat sebenarnya merupakan sistem adaptif, karena masyarakat merupakan wadah untuk memenuhi berbagai kepentingan dan tentunya juga untuk dapat bertahan. Masyarakat sendiri juga mempunyai berbagai kebutuhan yang harus dipenuhi agar masyarakat dapat hidup terus. Untuk itulah masyarakat selalu bekerjasama dan hidup berdamingan. Satlinmas selaku salah satu anggota masyarakat selalu terlibat dalam berbagai kegiatan. Bentuk partisipasi Satlinmas dalam kegiatan sosial kemasyarakatan seperti ketika ada salah satu warga yang meninggal atau pada saat ada acara perkawinan. Satlinmas turut serta 
mengatur keamanan agar kegiatan tersebut berjalan dengan baik

Peran Satlinmas yang keempat adalah membantu dalam terselenggaranya pemilu. Situasi menjelang dan sesudah pemilu perlu diwaspadai karena rawan terhadap kerusuhan karena adanya pihak yang bersitegang antar pendukung calon atau tidak menerima terhadap hasil pemilu. Kondisi seperti ini rawan memunculkan konflik dalam masyarakat. Secara teoritis, konflik lahir dari interaksi antara individu atau kelompok dalam aktivitas sosial, ekonomi, politik dan budaya (Affandi, 2004 73). Dalam kondisi ini Satlinmas ikut serta dalam menjaga situasi agar tidak terjadi bentrokan antar pendukung calon. Satlinmas juga membantu satpol PP dalam menertibkan atribut kampanya dan membantu mengamankan proses jalannya pemilu.

Peran Satlinmas yang kelima adalah membantu upaya pertahanan Negara. Satlinmas merupakan salah satu elemen dalam sishankamrata. Berdasarkan Undangundang Republik Indonesia No. 3 Tahun 2002 tentang Pertahanan Negara, pertahanan negara dimaknai sebagai segala usaha untuk mempertahankan kedudukan negara, keutuhan wilayah negara kesatuan republik Indonesiadan keselamatan segenap bangsa dari ancaman dan gangguan terhadap keutuhan bangsa dan negara. Sementara itu, pengertian sistem pertahanan negara menurut UU No. 3 Tahun 2002 adalah sistem pertahanan yang bersifat semesta,yang melibatkan seluruh warga negara, wilayah, dan sumber daya nasional lainnya, serta dipersiapkan secara dini oleh pemerintah dan diselenggarakan secara total, terpadu, terarah, dan berlanjut untuk menegakkan kedaulatan negara, keutuhan wilayah dan keselamatan segenap bangsa dari segala ancaman.

Komponen utama dalam pertahanan dan keamanan bangsa Indoneisa adalah Tentara Nasional Indonesia, yang siap digunakan untuk melaksanakan tugas-tugas pertahanan. Selain itu ada dua komponen lainnya yaitu komonen cadangan dan pendukung. Komponen cadangan adalah sumber daya nasional yang telah disiapkan untuk dikerahkan melalui mobilisasi guna memperbesar dan memperkuat kekuatan dan kemampuan komponen utama. Komponen pendukung Komponen pendukung adalah sumber daya nasional yang dapat digunakan untuk meningkatkan kekuatan dan kemampuan komponen utama dan komponen cadangan. Komponen pendukung tidak membentuk kekuatan nyata untuk perlawanan fisik. Komponen pendukung terdiri dari para militer, Polisi (Brimob), Satuan Polisi Pamong Praja (Satpol PP), Perlindungan masyarakat(Linmas) lebih dikenal dengan sebutan pertahanan sipil (Hansip), Satuan pengamanan (Satpam). Resimen Mahasiswa (Menwa), Organisasi kepemudaan dan . Organisasi bela diri. Telah dijelaskan dalam Undang-undang Dasar 1945 pasal 30 ayat (2) bahwa sistem pertahanan dan keamanan negara kita melibatkan seluruh rakyat Indonesia, tanpa terkecuali. Semua komponen bekerjasama, saling menguatkan satu sama lain. Tentara Nasional Indonesia dan Kepolisian Negara Republik Indonesia di barisan depan, rakyat memberikan dorongan dan dukungan sehingga pertahanan dan keamanan kita kuat. Dengan pertahanan yang kuat, bangsa Indonesia dapat melaksanakan pembangunan dengan sebaik-baiknya demi mencapai kesejahteraan rakyat.

Optimalisasi peran Satlimas dilakukan dengan aktif berpartisipasi dalam berbagai kegiatan yang dilaksanakan oleh kelurahan maupun pihak lain. Satlinmas juga aktif mambantu TNI dan Polri dalam mewujudkan keamanan, ketertiban keamanan dalam masyarakat. Adanya Satlinmas merupakan salah satu bentuk dari Sistem Pertahanan dan Keamanan Rakyat Semesta. Sistem ini menuntut partisipasi dari semua lapisan dalam masyarakat untuk ikut serta dalam menjaga dan mempertahankan pertahanan 
dan keamanan Indonesia. Made Pidarta dalam Siti Irene Astuti D. (2009: 31-32) menyatakan partisipasi adalah pelibatan seseorang atau beberapa orang dalam suatu kegiatan. Partisipasi masyarakat menurut Isbandi (2007: 27) adalah keikutsertaan masyarakat dalam proses pengidentifikasian masalah dan potensi yang ada di masyarakat, pemilihan dan pengambilan keputusan tentang alternatif solusi untuk menangani masalah, pelaksanaan upaya mengatasi masalah, dan keterlibatan masyarakat dalam proses mengevaluasi perubahan yang terjadi. Mikkelsen (1999: 64) membagi partisipasi menjadi 6 (enam) pengertian, yaitu:

1) Partisipasi adalah kontribusi sukarela dari masyarakat kepada proyek tanpa ikut serta dalam pengambilan keputusan;

2) Partisipasi adalah "pemekaan" (membuat peka) pihak masyarakat untuk meningkatkan kemauan menerima dan kemampuan untuk menanggapi proyek-proyek pembangunan;

3) Partisipasi adalah keterlibatan sukarela oleh masyarakat dalam perubahan yang ditentukannya sendiri;

4) Partisipasi adalah suatu proses yang aktif, yang mengandung arti bahwa orang atau kelompok yang terkait, mengambil inisiatif dan menggunakan kebebasannya untuk melakukan hal itu;

5) Partisipasi adalah pemantapan dialog antara masyarakat setempat dengan para staf yang melakukan persiapan, pelaksanaan, monitoring proyek, agar supaya memperoleh informasi mengenai konteks lokal, dan dampak-dampak sosial;

6) Partisipasi adalah keterlibatan masyarakat dalam pembangunan diri, kehidupan, dan lingkungan mereka.

Satlinmas telah berpartisipasi dalam pembangunan Indonesia dalam bentuk keaktifan membantu Pemda, TNI, Polri dan semua instansi yang terkait dalam mewujudkan Indonesia yang tertib, aman dan nyaman.
Partisipasi masyarakat diperlukan dalam mensukseskan pembangunan Indonesia. Conyers (1991: 154-155) menyampaikan pentingnya partsisipasi antara lain:

1. partisipasi masyarakat merupakan suatu alat guna memperoleh informasi mengenai kondisi, kebutuhan, dan sikap masyarakat setempat, yang tanpa kehadirannya program pembangunan serta proyek-proyek akan gagal

2. bahwa masyarakat akan lebih mempercayai proyek atau program pembangunan jika merasa dilibatkan dalam proses persiapan dan perencanaannya, karena mereka akan lebih mengetahui seluk-beluk proyek tersebut dan akan mempunyai rasa memiliki terhadap proyek tersebut;

3. bahwa merupakan suatu hak demokrasi bila masyarakat dilibatkan dalam pembangunan masyarakat mereka sendiri.

Keberadaaan Satlinmas, membantu pemerintah dan masyarakat dalam menggali, menata dan menciptakan lingkungan yang kondusif.

\section{KESIMPULAN}

Optimalisasi peran Satlinmas merupakan upaya penting dalam meningkatkan partisipasi masyarakat dalam menciptakan keamanan, ketertiban, dan ketenteraman di lingkungan masing-masing. Optimalisasi dilakukan sesuai dengan peran Satlinmas yang tertuang dalam Permendagri No.84 tahun 2014 dan Peraturan Wali Kota Surakarta No.58 A tahun 2012. Peran pertama membantu penanggulangan bencana. Untuk mengoptimalisasi perannya dalam penanggulangan bencana, Satlinmas aktif dalam berbagai kegiatan seperti normalisasi sungai, menjaga kebersihan sungai, pelatihan tanggap bencana, dan pengawasan debit air. Dalam melaksanakan kegiatan ini Satlinmas bekerjasama dengan masyarakat setempat. 
Penanggulangan ledakan penyakit juga dilakukan dengan aktif membantu kegiatan sosialisasi $3 \mathrm{M}$ dan membatu terselenggaranya acara HCT.

Peran Satlinmas yang kedua adalah membantu terciptanya keamanan, ketentraman dan ketertiban. Satlinmas Kelurahan Gilingan melakukan tugasnya secara optimal dalam terciptanya keamanan, kenyamanan dan ketertiban. Satlinmas Gilingan secara rutin melakukan patroli keliling terutama di tempat-tempat yang ramai masyarakat seerti tempat wisata. Satlinmas juga membantu satpol PP dalam melakukan operasi pekat karena banyaknya PSK di wilayah sekitar terminal. Untuk mengantisipasi peredaran gelap narkoba, Satlinmas Gilingan juga menjadi mitra kepolisian dalam mengawasi adanya indikasi peredaan narkoba. Selain itu, satlimas juga selalu membantu terselenggaranya acara kebudayaan di kelurahan Gilingan.

Peran Satlinmas yang ketiga adalah membantu dalam kegiatan sosial kemasyarakatan. Salah satu peran satlinmas yang paling dekat dengan masyarakat adalah membantu dalam kegiatan sosial kemasyarakatan. Satlinmas selalu terlibat dalam berbagai kegiatan seperti ketika ada salah satu warga yang meninggal atau pada saat ada acara perkawinan. Peran Satlinmas yang keempat adalah membantu dalam terselenggaranya pemilu. Satlinmas membantu dalam penertiban atribut kampanye, menjaga kondusifitas lingkungan sebelum dan setelah pemilu dan membantu terselenggaranya pemilu dengan lancar. Peran Satlinmas yang kelima adalah membantu upaya pertahanan Negara. Satlinmas merupakan salah satu elemen dalam sishankamrata. Dalam Hal ini Satlinmas mendapatkan pelathan dari Babinsa TNI untuk membantu menciptakan kondisi lingkungan yang kondusif.

Optimalisasi peran Satlinmas ini didukung oleh semua pihak yang terkait.
Dalam rangka optimalisasi ini semua pihak bekerjasama dalam mewujudkan suasana yang kondusif. Keterbukaan Polri dalam melibatkan Satlinmas untuk menjadi agen dalam mengawasi lingkungan sekitar masingmasing. Babinsa TNI juga selalu memberikan pelatihan tentang pertahanan. Dukungan dari pemerintah daerah tentunya juga sangat mendukung dengan tetap meberikan sarana dan prasarana yang dibutuhkan seperti perlengkapan seragam, alat keamanan, alat transportasi. Namun, terdapat pula hambatan dalam optimalisasi peran Satlinmas yaitu minimnya anggota Satlinmas. Jumlah anggota Satlinmas adalah 22 orang dengan rincian 9 orang tanpa SK dan 13 dengan SK. Minimnya jumlah anggota satlinmas ini menjadi tantangan tersendiri dalam tetap mengawasi seluruh wilayah.

\section{DAFTAR PUSTAKA}

Affandi. (2004). Akar Konflik Sepanjang Zaman; Elaborasi Pemikiran Ibn Khaldun. Yogyakarta: Pustaka Pelajar.

Astuti.D., S. I. (2009). Desentralisasi dan Partispasi dalam Pendidikan. Yogyakarta: UNY.

Bappeda. (2012). Hasil Monitoring Evaluasi dan Pelaporan Satuan Perlindunan Masyarakat Kota Surakarta tahun 2012. Surakarta: Bappeda Kota Surakarta.

Bappeda. (2016). Kajian deteksi Dini Kerawanan Sosial dan Kriminalitas Kota Surakarta tahun 2016. Surakarta: Bappeda Kota Surakarta.

Conyers, D. (1991). Perencanaan Sosial Dunia Ketiga. Yogyakarta: UGM Press.

Huberman, M., \& Saldana. (2014). Qualitative Data Analysis.: . United State America: SAGE. 
Isbandi. (2007). Perencanaan Partisipatoris Berbasis Aset Komunikasi: dari Pemikiran Menuju Penerapan. Depok: FISIP UI Press.

Maslow, A. H. (1994). Motivasi dan Kepribadian (Teori Motivasi dengan Pendekatan hierarki Kebutuhan Manusia). Jakarta: PT. PBP.

Soekanto, S. (2007). Sosiologi Suatu Pengantar. Jakarta: PT. Raja Grafindo.

Peraturan-peraturan:

1. Undang-Undang Dasar Negara Republik Indonesia 1945

2. UU No 24 Tahun 2007 Tentang Penanggulangan Bencana

3. Undang-undang Nomor 2 Tahun 2002 Tentang Kepolisian Negara Republik Indonesia

4. Undang-undang Republik Indonesia No. 3 Tahun 2002 tentang Pertahanan Negara

5. Peraturan Walikota Surakarta Nomor 58-A Tahun 2012 Tentang Pelindungan Masyarakat

6. Peraturan Menteri Dalam Negeri No.84 Tahun 2014 Tentang Penyeleggaraan Perlindungan Masyarakat 